\title{
In vitro anti-cancer activity of two ethno-pharmacological healing plants from Guatemala Pluchea odorata and Phlebodium decumanum
}

\author{
MANUELA GRIDLING $^{1}$, NICOLE STARK ${ }^{1}$, SIBYLLE MADLENER $^{1}$, ANDREAS LACKNER $^{4}$, \\ RUXANDRA POPESCU ${ }^{5}$, BIRGIT BENEDEK ${ }^{5}$, RENE DIAZ ${ }^{8}$, FOSTER M. TUT ${ }^{8}$, \\ THANH PHUONG NHA VO ${ }^{1,6}$, DANIELA HUBER ${ }^{1}$, MICHAELA GOLLINGER $^{1}$, PHILIPP SAIKO $^{2}$, \\ ALI ÖZMEN ${ }^{9}$, WILHELM MOSGOELLER ${ }^{4}$, RAINER DE MARTIN ${ }^{3}$, RUTH EYTNER $^{3}$, \\ KARL-HEINZ WAGNER ${ }^{7}$, MICHAEL GRUSCH ${ }^{4}$, MONIKA FRITZER-SZEKERES ${ }^{2}$, \\ THOMAS SZEKERES ${ }^{2}$, BRIGITTE KOPP ${ }^{5}$, RICHARD FRISCH ${ }^{8}$ and GEORG KRUPITZA $^{1}$ \\ ${ }^{1}$ Institute of Clinical Pathology, ${ }^{2}$ Clinical Institute of Medical and Chemical Laboratory Diagnostics, \\ ${ }^{3}$ Department of Vascular Biology and Thrombosis Research, Medical University of Vienna, Waehringer Guertel 18-20, \\ Vienna; ${ }^{4}$ Department of Medicine I, Division of Cancer Research, Medical University of Vienna, Borschkegasse 8a, Vienna; \\ ${ }^{5}$ Department of Pharmacognosy, ${ }^{6}$ Department of Pharmaceutical Chemistry, Faculty of Life Sciences, ${ }^{7}$ Department \\ of Nutritional Sciences, University of Vienna, Althanstrasse 14, Vienna, Austria; ${ }^{8}$ Institute for Ethnobiology, Playa Diana, \\ San José/Petén, Guatemala; ${ }^{9}$ Institute of Biology, Fen-Edebiyat Fakültesi, Adnan Menderes Üniversitesi, Aydin, Turkey
}

Received July 16, 2008; Accepted November 18, 2008

DOI: 10.3892/ijo_00000239

\begin{abstract}
Many traditional healing plants successfully passed several hundred years of empirical testing against specific diseases and thereby demonstrating that they are well tolerated in humans. Although quite a few ethnopharmacological plants are applied against a variety of conditions there are still numerous plants that have not been cross-tested in diseases apart from the traditional applications. Herein we demonstrate the anti-neoplastic potential of two healing plants used by the Maya of the Guatemala/Belize area against severe inflammatory conditions such as neuritis, rheumatism, arthritis, coughs, bruises and tumours. Phlebodium decumanum and Pluchea odorata were collected, dried and freeze dried, and extracted with five solvents of increasing polarity. We tested HL-60 and MCF-7 cells, the inhibition of proliferation and the induction of cell death were investigated as hallmark endpoints to measure the efficiency of anti-cancer drugs. Western blot and FACS analyses elucidated the underlying mechanisms. While extracts of $P$. decumanum showed only moderate anti-cancer
\end{abstract}

Correspondence to: Professor Georg Krupitza, Institute of Clinical Pathology, Medical University of Vienna, Waehringer Guertel 18-20, A-1090 Vienna, Austria

E-mail: georg.krupitza@meduniwien.ac.at

Key words: Pluchea odorata, anti-inflammatory, anti-neoplastic, apoptosis, cell cycle arrest activity and were therefore not further analysed, particularly the dichloromethane extract of $P$. odorata inhibited the cell cycle in G2-M which correlated with the activation of checkpoint kinase 2, and down-regulation of $\mathrm{Cdc} 25 \mathrm{~A}$ and cyclin D1 as well as inactivation of Erk1/2. In HL-60 and MCF-7 cells this extract was a very strong inducer of cell death activating caspase- 3 followed by PARP signature type cleavage. The initiating death trigger was likely the stabilization of microtubules monitored by the rapid acetylation of $\alpha$-tubulin, which was even more pronounced than that triggered by taxol. The dichloromethane extract of $P$. odorata contains apolar constituents which inhibit inflammatory responses and exhibit anti-cancer activity. The strong proapoptotic potential warrants further bioassay-guided fractionation to discover and test the active principle(s).

\section{Introduction}

Over $60 \%$ of all drugs used in Western medicine are derived from natural compounds which served as leads (1), where of the majority has been discovered in terrestrial plants and microbes (2). For instance Catharanthus roseus (source of the anti-cancer alkaloids vincristine und vinblastine) is frequently used by Belizian 'bush doctors' (herbalists) to slow tumour growth and to treat sore throats. Also Taxol (Paclitaxel), which naturally occurs in the bark of the evergreen Pacific yew tree (Taxus brevifolia), is applied against breast cancer. Taxol stabilizes microtubules and therefore interferes with spindle-formation and this prevents cell division (3). Apparently, specific toxins provide an evolutionary advantage, because many of the bioactive compounds in plants seem to play a part in defence mechanisms. Also anti-oxidants 
(e.g. vitamins), which protect the cells from oxidative DNA damage, have been shown to be effective in cancer prevention and suppress chronic inflammation (4). Inflammation involves the activation of enzymes and intracellular pathways which are also frequently up-regulated in tumour cells. Examples of such common pathways include signaling via TNF $\alpha$ NFkB/Rel, COX-2-prostanoids, ß-catenin-GSK, and MEKErk (5-7).

One way to discover new leads for pharmaceutical development is the random screening of the biosphere. From the 80s up to now, pharmaceutical companies are collecting marine life forms, bacteria, fungi and plants at random to test them in robot-screening facilities regarding their anti-cancer, anti-inflammatory, anti-bacterial etc. activities, however at very high costs. Another approach makes use of the ancient ethno-botanical knowledge of traditional medicines which mostly relies on the in depth empirical experiences with the locally available natural resources, mainly plants. We have therefore, focussed our interest on the knowledge of herbalists and curanderos/curanderas of very old cultures or civilizations living in high biodiversity regions still practising their traditional healing methods based on a rich botanical pharmacy. The long-lasting medicinal experience of the Mayas is a particularly precious knowledge, and moreover, some Maya populations have been rather isolated for hundreds of years and still treat diseases of many kinds using natural remedies from the neighbouring tropical rain forests, which are among the richest biodiversity areas in the world. Since the Maya medicine neither knew about leukemia or cancer, nor remedies against it, our concept of plant selection was their traditional use (and they still are in use) against severe inflammations, because there are a variety of similar signalling pathways which are commonly up-regulated both in inflammatory conditions and in cancer. In this investigation the criteria for plant selection were: i) the traditional use to treat inflammatory conditions; and ii) the absence of records in Western medicinal and patent databases.

In this manner, we selected two well tolerated (in terms of side effects) healing plants, which are still used by the Maya of the Guatemala/Belize lowland rain forests against various inflammatory conditions (i.e. arthritis, gastritis), to study their possible in vitro anticancer activity. This approach is highly focussed and saves from more than $99 \%$ unsuccessful 'trials and errors' of broad spectrum screening (i.e. as done by large pharmaceutical companies) and may offer a higher probability of finding new lead compounds against cancer. An important feature of currently used anti-cancer drugs is their potential to trigger programmed cell death (apoptosis) and to inhibit cell cycle progression. Thus, it is relevant to investigate whether cell cycle inhibition and apoptosisinduction are initiated by novel anti-cancer drugs, because these mechanisms are required to regulate tissue homeostasis, but are frequently impaired in cancer cells. Taxol, is a major anti-cancer drug derived from the genus Taxa $s p$. (Pacific yew) $(8,9)$ and tubulin stabilization by taxol is reflected by the increased acetylation of $\alpha$-tubulin at lysine 40 (10). Tubulins are the major constituents of microtubules, which are necessary for chromosome disjunction during mitosis, and therefore, the deregulation of tubulin dynamics is incompatible with functional cell division (11). The stabilization of microtubules by taxol causes mitotic arrest (mitotic catastrophe) and in consequence apoptosis. Thus, the tubulin-stabilising potential of pro-apoptotic plant extracts is routinely studied in our investigations. Here we describe for the first time the anti-cancer activity of extracts of two ethno-pharmacological healing plants used against various inflammatory scenarios, Pluchea odorata (Asteracea) and Phlebodium decumanum (Polypodiacea), in HL-60 promyeloic leukaemia cells and MCF-7 breast cancer cells.

\section{Materials and methods}

Plant material. Leaves and rhizomes of Phlebodium decumanum and the aerial parts of Pluchea odortata were collected in Playa Diana, San José/Petén, Guatemala in August, 2006, and identified by Dr Richard Frisch of the Institute of Ethnobotany, San Jose, EL Peten, Guatemala. Voucher specimens were deposited in the Herbarium of the Institute of Ethnobotany, Playa Diana, San José/Petén.

Extraction. Leaves and rhizomes of $P$. decumanum $(50 \mathrm{~g})$ and the aerial plant parts of P. odorata $(50 \mathrm{~g})$ were partly air-dried, partly freeze dried and ground. The plant material was extracted with petroleum ether, dichloromethane, ethyl acetate, methanol and water successively $(500 \mathrm{ml})$. The extracts were evaporated under vacuum and the residues were resolved in ethanol for testing. The dried extracts were dissolved in $2 \mathrm{ml}$ ethanol. For the proliferation and apoptosis assay following concentrations were used: $500 \mu \mathrm{g} / \mathrm{ml}$, $1 \mathrm{mg} / \mathrm{ml}, 4 \mathrm{mg} / \mathrm{ml}, 20 \mathrm{mg} / \mathrm{ml}$, as well as $0.2 \% \mathrm{EtOH}$ solvent control. Forty $\mathrm{mg} / \mathrm{ml}$ was the concentration in which the extract remained dissolved when added to the cell culture medium but exhibited non-specific toxicity inducing necrosis (data not shown). Therefore, we used only $20 \mathrm{mg} / \mathrm{ml}$ as the highest tested concentration.

Reagents and antibodies. Hoechst 33258, propidium iodide and paclitaxel were purchased from Sigma. Pierce ECL Western blotting substrate Cat\# 32106 was from Pierce. Antibodies: mouse monoclonal anti-acetylated tubulin clone 6-11B1 Cat\# T6793, and mouse monoclonal anti-ß-actin clone AC-15 Cat\# A5441, were from Sigma. Mouse monoclonal anti cdc25A (F-6) Cat\# 7389, anti $\alpha$-tubulin (TU-02) Cat\# sc-8035, anti ß-tubulin (H-235) Cat\# sc-9104, PARP-1 (F-2) Cat\# sc-8007, and anti-cyclin D1 (M-20) Cat\# sc-718 were from Santa Cruz Biotechnology Inc. Mouse monoclonal p27kip Cat\# 610241 was from Transduction Laboratories. Rabbit monoclonal anti-active caspase-3 (CPP32) clone C92-605 Cat\# 58404 was from Research Diagnostics Inc. Polyclonal, anti-phospho-Chk2 (Thr68) Cat\#2661, anti-Chk2 Cat\# 2662, monoclonal rabbit anti-p44/42 MAP Kinase (Erk1/2; 137F5) Cat\# 4695, and mouse monoclonal antiphospho-p44/42 MAPK (Erk1/2-Thr202/Tyr204) (E10) Cat\# 9106 were from Cell Signaling. Anti-mouse IgG was from Dako and anti-rabbit IgG from GE-Healthcare. Amersham Hyperfilms ECL, high performance chemiluminescence film was from GE-Healthcare.

Cell culture. HL-60 promyelocytic leukemia, MCF-7 breast cancer cells, and MCF-10A immortalized non-tumorigenic 
fibrocystic mammary gland epithelial cells were from ATCC. Cells were grown in RPMI-1640 (HL-60) or DMEM (MCF-7, MCF-10A) medium supplemented with $10 \%$ heat inactivated fetal calf serum, $1 \%$ L-glutamine and $1 \%$ penicillin/streptomycin at $37^{\circ} \mathrm{C}$ in a humidified atmosphere containing $5 \%$ $\mathrm{CO}_{2}$. All media and supplements were obtained from Life Technologies.

Proliferation inhibition assay. Three different cell types were used: HL-60, MCF-7 and MCF-10A. To determine the antiproliferative effect of the plant extracts HL-60 cells were seeded in T-25 tissue culture flasks at a concentration of $0,1 \times 10^{6}$ cells per ml. MCF-7 and MCF-10A were seeded at a concentration of $0.01 \times 10^{6}$ cells per $\mathrm{ml}$ in 24 -well plates and grown for $24 \mathrm{~h}$. Then they were incubated with increasing concentration of plant extracts $(500 \mu \mathrm{g} / \mathrm{ml}, 1 \mathrm{mg} / \mathrm{ml}, 4 \mathrm{mg} / \mathrm{ml}$, $20 \mathrm{mg} / \mathrm{ml}$ ) for $72 \mathrm{~h}$. After 24 and $72 \mathrm{~h}$ cell counts and $\mathrm{IC}_{50}$ values for plant extracts were determined by dint of a microcellcounter. MCF-7 and MCF-10A had to be trypsinised and washed with PBS before. Experiments were done in triplicate. The percent of cell divisions compared to the untreated control were calculated as follows: $\left[\left(\mathrm{C}_{48 \mathrm{~h}+\text { drug }}-\mathrm{C}_{24 \mathrm{~h}+\text { drug }}\right) /\right.$ $\left.\left(\mathrm{C}_{48 \mathrm{~h}-\text { drug }}-\mathrm{C}_{24 \mathrm{~h}-\text { drug }}\right)\right] \times 100=\%$ cell division; $\mathrm{C}$, cell number.

Hoechst 33258 and propidium iodide double staining. DNA staining with Hoechst was performed according to the method described by Grusch et al (12). HL-60 cells ( $1 \times 10^{5}$ per ml) were seeded in T-25 Nunc tissue culture flask and exposed to increasing concentrations of plant extracts $(500 \mu \mathrm{g} / \mathrm{ml}$, $1 \mathrm{mg} / \mathrm{ml}, 4 \mathrm{mg} / \mathrm{ml}, 20 \mathrm{mg} / \mathrm{ml}$ ) for $48 \mathrm{~h}$. MCF-7 cells were seeded at a density of 10,000 cells/ml in $24-w e l l$ plates and grown for $24 \mathrm{~h}$. Then, increasing concentrations of extract were added and the cells were treated for $96 \mathrm{~h}$, which was the time-point when MCF-7 cells were analysed for apoptotic nuclear morphology. Then the cells were washed with PBS, treated with trypsin and resuspended with medium. Hoechst 33258 and propidium iodide were added directly to the cells at final concentrations of $5 \mu \mathrm{g} / \mathrm{ml}$ and $2 \mu \mathrm{g} / \mathrm{ml}$, respectively. After $60 \mathrm{~min}$ of incubation at $37^{\circ} \mathrm{C}$, cells were examined on a Zeiss Axiovert fluorescence microscope equipped with a DAPI filter. Cells were photographed and analyzed by visual examination (not by FACS). This method allows to distinguishing between apoptosis and necrosis $(12,13)$. Cells were judged according to their morphology and the integrity of their cell membranes, which can easily be seen upon propidium iodide staining.

Western blotting. HL-60 cells $\left(1.5 \times 10^{7}\right)$ were seeded into $\mathrm{T}-75$ Nunc tissue culture flasks and incubated with selected $4 \mathrm{mg} / \mathrm{ml}$ dichloromethane extract of P. odorata and Lactuca sativa for $0.5,2,4,8$ and $24 \mathrm{~h}$. Then $1 \times 10^{6}$ cells were harvested (per experimental point), washed twice with ice cold PBS, centrifuged at 1,000 rpm for $5 \mathrm{~min}$, lysed in a buffer containing $150 \mathrm{mM} \mathrm{NaCl}, 50 \mathrm{mM}$ Tris $\mathrm{pH} \mathrm{8.0, \% 1}$ Triton X-100, $1 \mathrm{mM}$ phenylmethylsulfonylfluorid (PMSF) and protease inhibitor cocktail (PIC; from a 100x stock). Then the lysate was centrifuged at $12,000 \mathrm{rpm}$ for $20 \mathrm{~min}$ at $4^{\circ} \mathrm{C}$, and the supernatant was stored at $-20^{\circ} \mathrm{C}$ until further analysis. Equal amounts of protein samples were separated by polyacrylamide gel electrophoresis (PAGE) and electrotransferred onto PVDF-membranes (Hybond, Amersham) at $4{ }^{\circ} \mathrm{C}$ overnight. Equal sample loading was controlled by staining membranes with Ponceau S. After washing with phosphate-buffered saline/Tween-20 (PBS/T) (pH 7.2) or Tris buffered saline/Tween-20 (TBS/T) (pH 7.6), membranes were blocked for $1 \mathrm{~h}$ in blocking solution (5\% non-fat dry milk in PBS containing $0.5 \%$ Tween-20 or in TBS containing $0.1 \%$ Tween-20). Then, membranes were incubated with the first antibody (in blocking solution, dilution 1:500-1:1000) by gently rocking at $4^{\circ} \mathrm{C}$, overnight. Thereafter, the membranes were washed with PBS or TBS and further incubated with the second antibody (peroxidase-conjugated goat anti-rabbit $\mathrm{IgG}$ or anti-mouse $\mathrm{IgG}$, dilution 1:2000-1:5000 in PBS/T or TBS/T) for $12 \mathrm{~h}$. Chemiluminescence was developed by the ECL detection kit (Amersham, UK) and then membranes were exposed to Amersham Hyperfilm.

CD62E (E-selectin, ELAM) induction assay. Each well of a 96-well plate was coated with gelatin $(200 \mu \mathrm{l} /$ well of $1 \%$ gelatin for $10 \mathrm{~min}$ at room temperature. Outer wells (A1A12/H1-H12/A1-H1/A12-H12) contained only $200 \mu \mathrm{l} /$ well medium and served as evaporation barrier. $\left(1 \times 10^{4}\right)$ HUVECs/ well/200 $\mu 1$ medium were seeded and grown for $48 \mathrm{~h}$ to reach optimal confluence. Prior to treatment with plant extracts medium was removed with a multi-channel pipet and collected in a reagent reservoir. Then, $100 \mu 1$ medium per well were back-transfered (no fresh medium was added, since that would have stimulated the HUVECs). Plant extracts were added in appropriate dilutions in triplicate and mixed by multi-channel-pipet and HUVECs were incubated with the extracts $1 \mathrm{~h}$ prior to TNF $\alpha$-stimulation. After a 4-h incubation with TNFa the experiment was analysed.

Cell surface ELISA CD62E. Cells were washed once with PBS and fixed with $100 \mu \mathrm{l} /$ well $25 \%$ glutaraldehyde (40 $\mu 1$ in $10 \mathrm{ml}$ PBS, Sigma \#G-5882, stocked at $-20^{\circ} \mathrm{C}$ in aliquot ampoules) for $15 \mathrm{~min}$ at room temperature. Then, cells were washed 3 times with $200 \mu \mathrm{l} /$ well PBS/0.05\% Tween-20, blocked with $200 \mu \mathrm{l} /$ well $5 \%$ BSA/PBS for $1 \mathrm{~h}$, and washed again 3 times with $200 \mu \mathrm{l} /$ well PBS/0.05\% Tween-20. Then, anti-ELAM-antibody 1:5000 in 0.1\% BSA/PBS (100 $\mu \mathrm{l} /$ well) was added for $1 \mathrm{~h}$ at room temperature and thereafter washed 5 times with $200 \mu \mathrm{l} /$ well PBS/ $0.05 \%$ Tween-20. Goat antimouse-HRP antibody $1: 10000$ in $0.1 \%$ BSA/PBS (100 $\mu 1 /$ well) was applied in the dark at room temperature for $1 \mathrm{~h}$ and then washed 5 times with $200 \mu \mathrm{l} /$ well PBS/0.05\% Tween-20. HRP-reaction was done with Fast-OPD (Sigma \#P-9187): one OPD tablet (silver foil) and one urea hydrogen peroxide tablet (gold foil) was vortexed in $20 \mathrm{ml} \mathrm{H}_{2} \mathrm{O}$ until dissolved and then $200 \mu 1$ substrate/well was added and incubated for up to $30 \mathrm{~min}$ in the dark. The reaction was stopped with $1 \mathrm{M} \mathrm{H}_{2} \mathrm{SO}_{4} 50 \mu \mathrm{l} /$ well and analyzed at $\mathrm{OD}_{492 \mathrm{~nm}}$.

Toxicity (SRB) assay. The Sulforhodamine B (SRB) protein staining assay measures the binding of dye to basic amino acids of cellular proteins of the confluent HUVEC layer and colorimetric evaluation provides an estimate of total protein mass which is related to the cell number. The assay plates were washed once with PBS prior to fixation, to eliminate 
a

Inhibition of TNF $\alpha$-induced $\mathrm{CD} 62 \mathrm{E}$ induction
by P.decumanum rhizome PE-extract

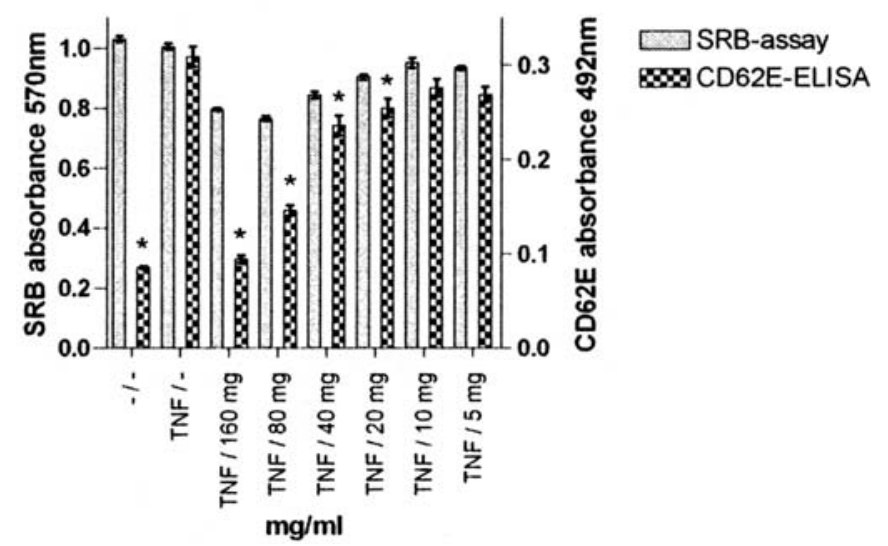

b

Inhibition of TNF $\alpha$-induced CD62E induction by $P$. odorata foliage DiMe-extract

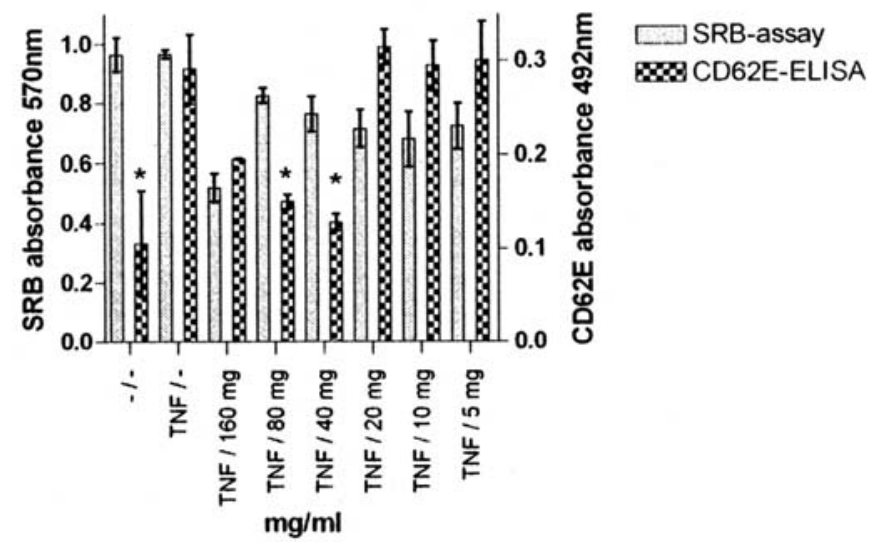

Figure 1. Inhibition of TNFa-triggered CD62E induction. HUVECs/well $\left(1 \times 10^{4}\right)$ were seeded into 96-well plates and grown to confluence. Serial dilutions of extracts were added $1 \mathrm{~h}$ prior application of TNFa, which was incubated for another $4 \mathrm{~h}$. Then cells were fixed and CD62E levels analysed by ELISA. In parallel extracts were analysed by sulforhodamine B assay (SRB) assay to monitor non-specific extract toxicity. (a) Petroleum ether (PE) rhizome extract of $P$. decumanum; (b) dichloromethane (DiMe) foliage extract of $P$. odorata. $\mathrm{mg}$-amounts refer to dried plant weight per $\mathrm{ml}$ cell culture medium. Error bars indicate SEM and asterisks significant differences compared to TNF $\alpha$ treatment $(\mathrm{p}<0.05)$.

dead cells. To each well of a 96-well plate $25 \mu \mathrm{l}$ of a $50 \%$ TCA solution was added to $100 \mu 1$ medium (final TCA conc. $10 \%$ ) and incubated at $4{ }^{\circ} \mathrm{C}$ overnight and then plates were washed 5 times with $\mathrm{H}_{2} \mathrm{O}(200 \mu l$ per well). Thereafter, $100 \mu 10.4 \% \mathrm{SRB} /$ well was added and incubated at room temperature for $20 \mathrm{~min}$. Then, plates were washed 5 times with $200 \mu 11 \%$ acetic acid/well, air dried for $10 \mathrm{~min}$ and then $200 \mu 110 \mathrm{mM}$ Tris Base solution/well were added and bound SRB was solubilized by shaking for $10 \mathrm{~min}$ and analyzed at $\mathrm{OD}_{570 \mathrm{~nm}}$. The experimental set up for toxicity (SRB-assay) as well as CD62E-expression was performed in an equal dilution series for all substances (dilutions used: $5,10,20,40,80,160 \mathrm{mg}$ dried plant weight per $\mathrm{ml}$ cell culture medium).

FACS analysis. HL-60 cells $\left(1 \times 10^{6}\right.$ per $\left.\mathrm{ml}\right)$ were seeded in T-25 Nunc tissue culture flasks and incubated with $500 \mu \mathrm{g} / \mathrm{ml}$, $1.0 \mathrm{mg} / \mathrm{ml}, 4 \mathrm{mg} / \mathrm{ml} \mathrm{P}$. odorata dichloromethane extract at $37^{\circ} \mathrm{C}$ under cell culture conditions. After $24 \mathrm{~h}$, cells were harvested, washed with $5 \mathrm{ml}$ cold PBS, centrifuged (800 rpm for $5 \mathrm{~min}$ ), and resuspended and fixed in $3 \mathrm{ml}$ cold ethanol (70\%) for $30 \mathrm{~min}$ at $4^{\circ} \mathrm{C}$. After two further washing steps with cold PBS, RNAse A and propidium iodide were added to a final concentration of $50 \mu \mathrm{g} / \mathrm{ml}$ each and incubated at $4^{\circ} \mathrm{C}$ for $60 \mathrm{~min}$ before measurement. Cells were analyzed on a FACSCalibur flow cytometer (BD Biosciences, San Jose, CA, USA) and cell cycle distribution was calculated with ModFit LT software (Verity Software House, Topsham, ME, USA).

Statistics. All experiments were done in triplicate and analysed by t-test (GraphPad Prism 4.0 program).

\section{Results}

Analysis of inflammatory response. Both plants, $P$. decumanum and P. odorata, were chosen because of their anti- inflammatory properties and applications in the traditional medicine of the Maya. Furthermore, $P$. decumanum products are sold as anti-inflammatory remedy. Here, we show that the petroleum ether of $P$. decumanum rhizome dose-dependently suppressed TNF $\alpha$-induced CD62E induction in HUVECs (Fig. 1), whereas the dichloromethane extract from rhizome or other extracts from foliage material did not (data not shown). Also $P$. odorata dichloromethane extract inhibited TNF $\alpha$-mediated CD62E induction (Fig. 1). This demonstrates that both plants exhibit anti-inflammatory properties in vitro, which supports the empirical observations of herbalists.

Anti-proliferative activity of $P$. decumanum extracts. $P$. decumanum foliage and rhizome extracts were derived from lyophilized material. All extracts were tested in HL-60 cells. As illustrated in Fig. 2, all extracts exhibited anti-proliferative effects of different magnitudes in HL-60 cells. The strongest activity was observed in the dichloromethane extract of foliage which inhibited growth by $\sim 80 \%$ (at $4 \mathrm{mg} / \mathrm{ml}$; the concentration which inhibited $50 \%$ of the proliferation; $\mathrm{I}_{\mathrm{p}} \mathrm{C}_{50}=2 \mathrm{mg} / \mathrm{ml}$ ), whereas the foliage methanol extract inhibited proliferation only by $60 \%\left(4 \mathrm{mg} / \mathrm{ml} ; \mathrm{I}_{\mathrm{p}} \mathrm{C}_{50}=3 \mathrm{mg} /\right.$ $\mathrm{ml})$. The water type was the weakest foliage extract. In general, rhizome extracts exhibited still weaker antiproliferative activity, whereby the rhizome petroleum ether extract was the strongest, inhibiting $\sim 25 \%$ of HL-60 proliferation $\left(4 \mathrm{mg} / \mathrm{ml} ; \mathrm{I}_{\mathrm{p}} \mathrm{C}_{50}=10 \mathrm{mg} / \mathrm{ml}\right)$.

Anti-proliferative activity of $P$. odorata extracts. $P$. odorata extracts were derived from aerial plant parts, which were either air-dried (Fig. 3a-e) or freeze-dried (Fig. 3f-j). HL-60 cells were subjected to increasing concentrations of the dissolved extract types (pertroleum ether, dichlormethane, ethylacetate, methanol, and water; mg-amounts relate to dried plant material before extraction) and then the percentage of cell division was calculated. The highest antiproliferative 


\section{Proliferation inhibition by $P$. decumanum freeze dried extracts}

Foliage

petroleum ether extract
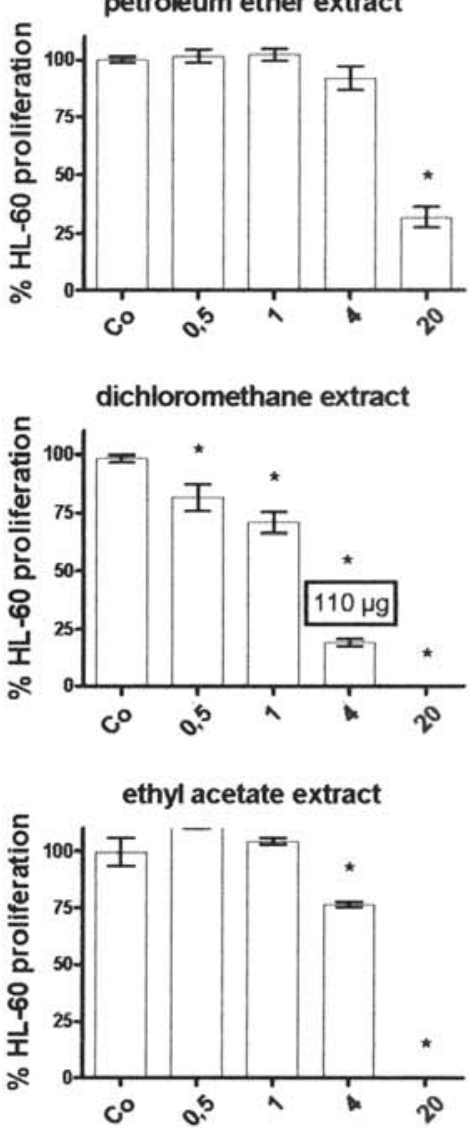

methanol extract

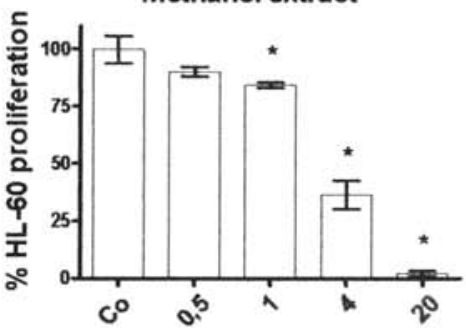

water extract

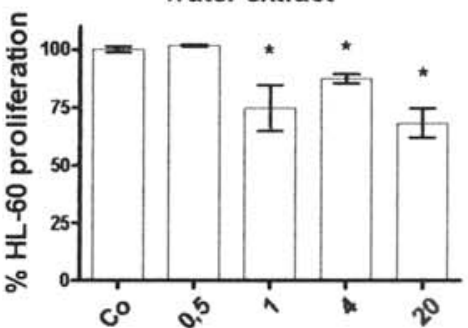

Rhizome

petroleum ether extract
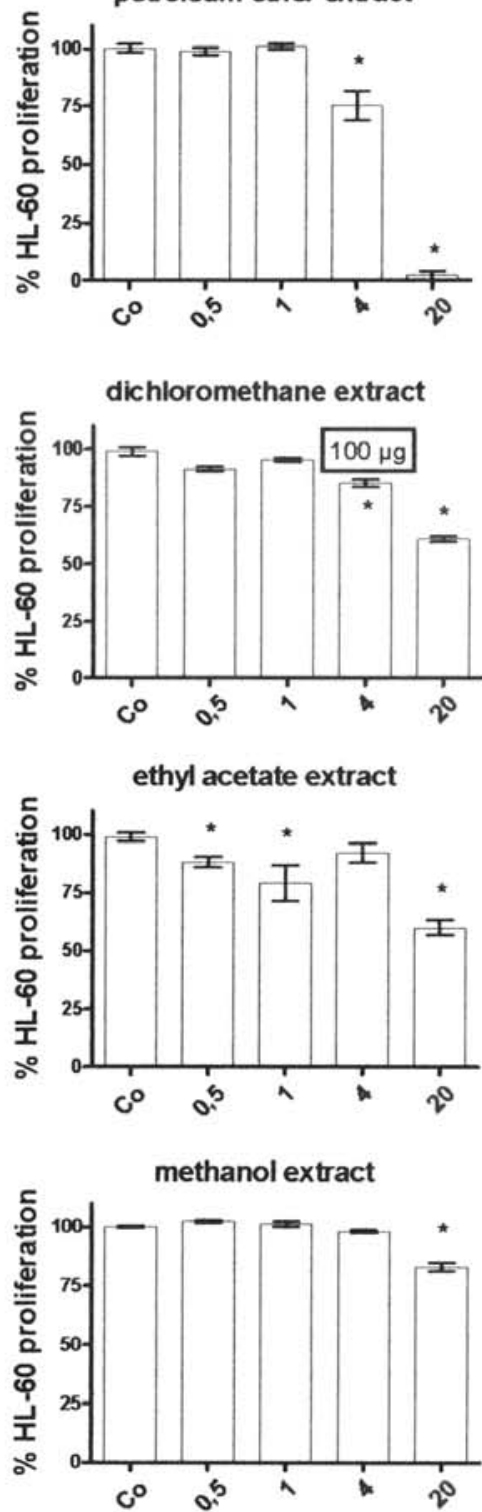

water extract

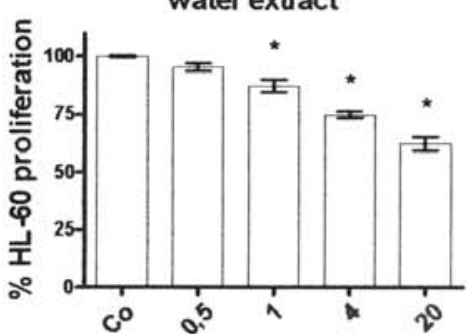

Figure 2. Anti-proliferative effect of $P$. decumanum extracts. HL-60 cells were seeded into T-25 tissue culture flasks ( $1 \times 10^{5}$ cells/ml), grown for 24 h to enter logarithmic growth phase, and incubated with $0.5,1,4$ and $20 \mathrm{mg} / \mathrm{ml}$ of plant extracts (mg-amounts relate to dried plant material before extractions). $P$. decumanum foliage and rhizomes were only analyzed as freeze-dried material. Controls received $0.2 \%$ EtOH which was the ethanol concentration cells received together with the highest extract concentration. The other samples were adjusted to equal ethanol concentrations to achieve similar solvent conditions Cells were counted after 24 and $48 \mathrm{~h}$ of treatment and the percentage of proliferation within this time span was calculated in comparison to controls (controls were considered as $100 \%$ proliferating cells and all other conditions were set in relation to this). Boxed $\mu$ g-amounts refer to dried extract weights per ml cell culture medium. Error bars indicate SEM, and asterisks significant proliferation inhibition compared to control ( $\mathrm{p}<0.05$ ). 


\section{Proliferation inhibition by $\boldsymbol{P}$. odorata extracts}

\section{air dried}

a

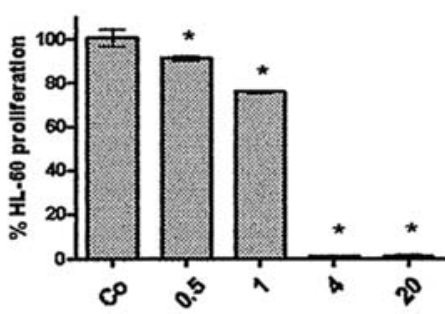

b dichloromethane extract

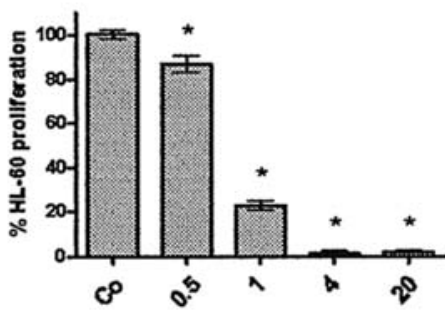

C ethyl acetate extract

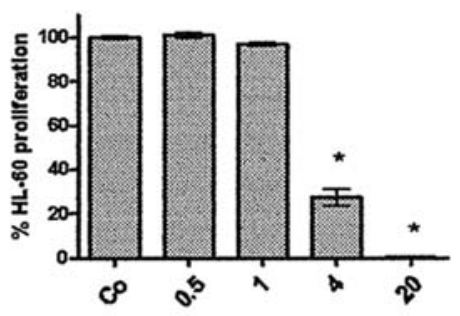

d

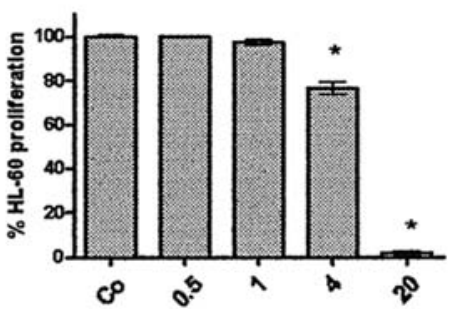

freeze dried

f petroleum ether extract

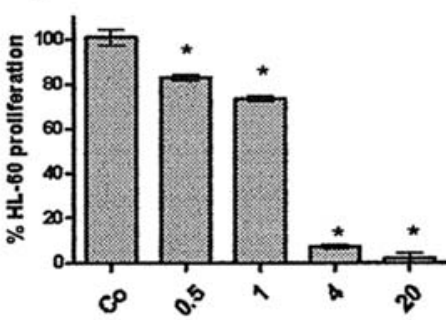

g dichloromethane extract

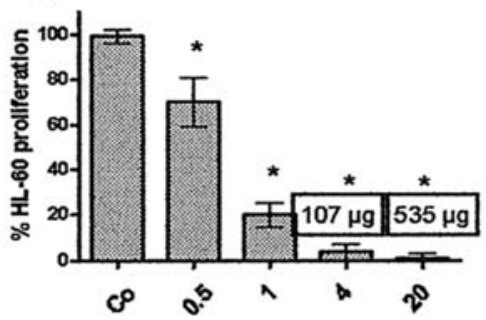

h ethyl acetate extract

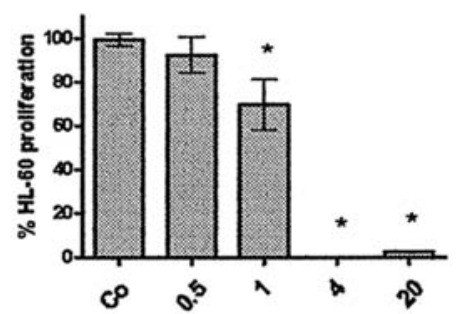

i methanol extract

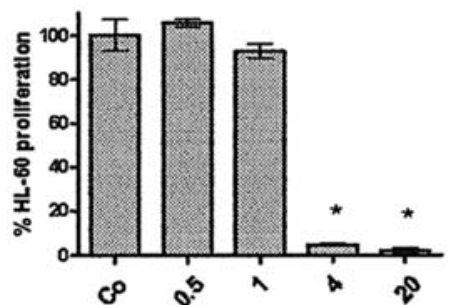

Figure 3. Part I. Anti-proliferative effects of $P$. odorata and $L$. sativa extracts.

activity was observed in the dichloromethane extract with an $\mathrm{I}_{\mathrm{p}} \mathrm{C}_{50}$ of $\sim 0.7 \mathrm{mg} / \mathrm{ml}$ (Fig. $3 \mathrm{~b}$ and g). Therefore, this plant was 3 -fold more active than $P$. decumanum and hence, further mechanistic analyses were performed only with the dichloromethane extract of $P$. odorata.

As a negative control the dichloromethane extract of Lactuca sativa (green salad) was tested, because this is not a pharmacological plant and can be consumed in considerable amounts. Dichloromethane extract of L. sativa $(4 \mathrm{mg} / \mathrm{ml})$ was non-toxic. Unexpectedly, the $20 \mathrm{mg} / \mathrm{ml}$ concentration (corresponding to $320 \mu \mathrm{g}$ dried extract $/ \mathrm{ml}$ ) exhibited significant anti-proliferative activity, which was stronger than that of $20 \mathrm{mg} / \mathrm{ml}$ (corresponding to $500 \mu \mathrm{g}$ dried extract $/ \mathrm{ml}$ ) $P$. decumanum dichloromethane extract derived from the rhizomes (Fig. $3 \mathrm{~m}$ ). This evidences, that the anti-proliferative properties of L. sativa, as compared to $P$. decumanum, was not an effect of random plant toxicity or due to extremely high residue amounts in the L. sativa dichloromethane extract, but specific due to unknown apolar constituents, which are possibly part of the green leaf material.

MCF-7 cells are frequently used in pharmacological studies because the vast majority of all agents, which exhibit activity in the NCI- 60 cell line screen, are also active in MCF-7 breast cancer cells (1). Therefore, the dichloromethane extract of $P$. odorata was tested in MCF-7 breast cancer cells (Fig. 3k) and, in order to compare it with a non-cancer cell line, in the human immortalized fibrocystic breast epithelial cell line MCF-10A (Fig. 31). In both breast cell lines the dichloromethane extract exhibited similar anti-proliferative effects, however, less efficient than observed in HL-60 cells. 

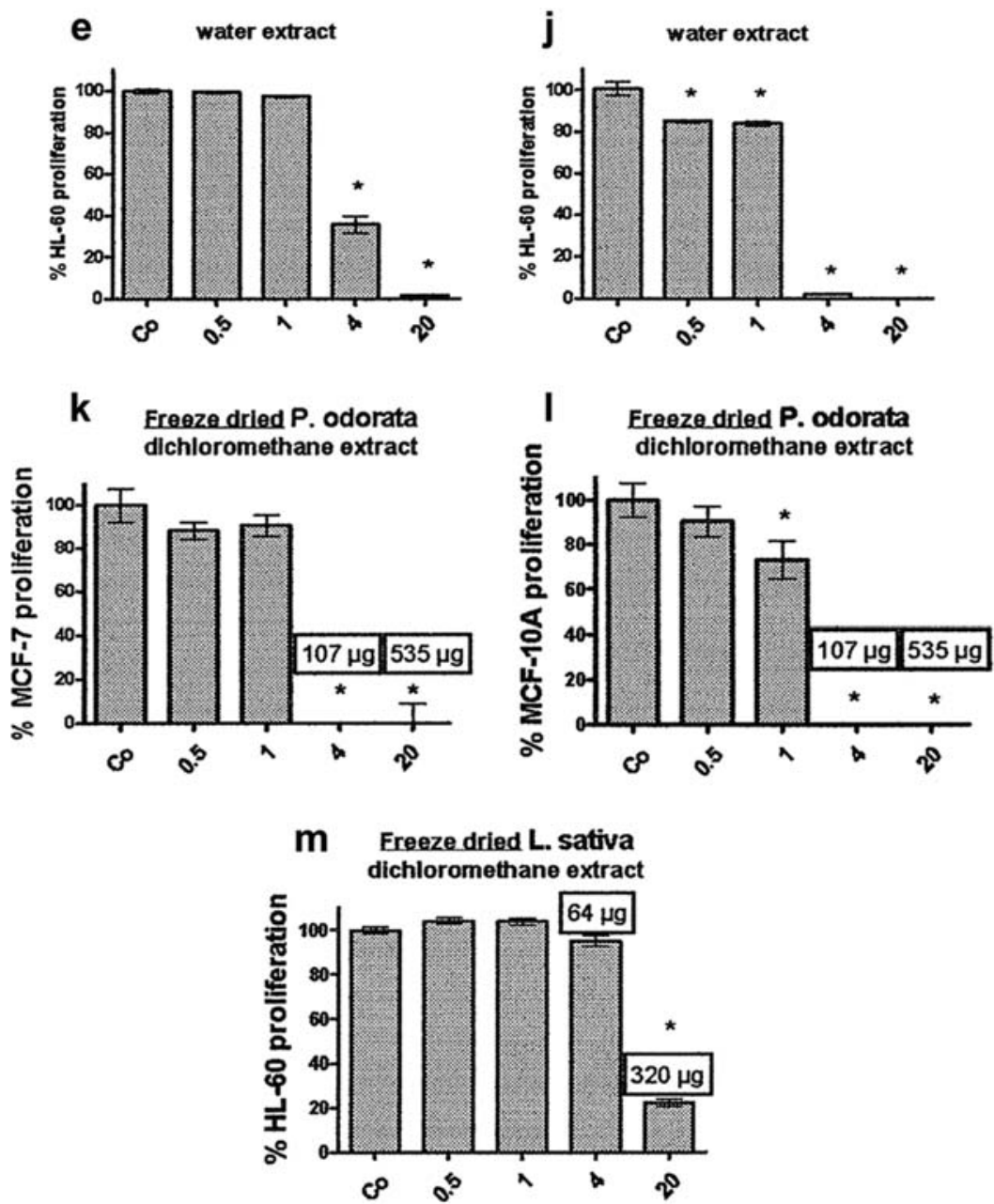

Figure 3. Anti-proliferative effects of $P$. odorata and L. sativa extracts. HL-60 cells were seeded into T-25 tissue culture flasks (1x10 ${ }^{5}$ cells/ml), grown for $24 \mathrm{~h}$ to enter logarithmic growth phase, and incubated with $0.5,1,4$ and $20 \mathrm{mg} / \mathrm{ml}$ of plant extracts (mg-amounts relate to dried plant material before extractions). Controls received $0.2 \% \mathrm{EtOH}$ which was the ethanol concentration which cells had to experience together with the highest extract concentration The other samples were also adjusted to equal ethanol concentrations to achieve similar solvent conditions. Cells were counted after 24 and $48 \mathrm{~h}$ of treatment and the percentage of proliferation between this time span was calculated in comparison to controls (controls were considered as $100 \%$ proliferating cells and all other values were set in relation to this). MCF-7 and MCF-10A cells were seeded in 24-well plates, allowed to attach for $24 \mathrm{~h}$ when extracts were applied as described above and cells counted after 24, 48 and $72 \mathrm{~h}$. Boxed $\mu$ g-amounts refer to dried extract weights per ml cell culture medium and show that the extract activity is very high. Error bars indicate SEM, and asterisks significant proliferation inhibition compared to control ( $\mathrm{p}<0.05$ ).

\section{Cell cycle distribution of HL-60 cells}

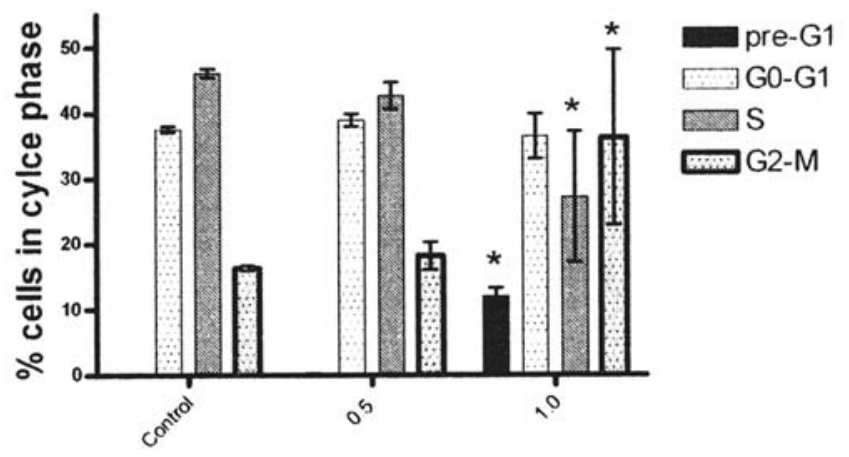

\section{P. odorata dichloromethane extract $(\mathrm{mg} / \mathrm{ml})$}

Figure 4. Cell cycle distribution of HL-60 cells upon treatment with P. odorato dichloromethane extract. Logarithmically growing HL-60 cells were incubated with 0.5 and $1.0 \mathrm{mg} / \mathrm{ml}$ extract for $24 \mathrm{~h}$ and then subjected to FACS analysis. Error bars indicate SEM and asterisks significance regarding the respective cell cycle phase of untreated controls $(\mathrm{p}=0.05)$.
Dichloromethane extract of $P$. odorata inhibits cell cycle in G2-M. HL-60 cells were incubated for $24 \mathrm{~h}$ with 0.5 and $1.0 \mathrm{mg} / \mathrm{ml}$ dichloromethane extract derived from aerial parts of $P$. odorata. Then, cellular DNA was stained and the respective cell cycle phase distribution was determined by FACS analysis. This extract inhibited cell cycle progression in the G2-M phase, as the number of cells in pre-G1 and G2-M significantly increased, whereas the number of $S$ phase cells decreased (Fig. 4).

Inhibition of proliferation is preceded by the downregulation of cell cycle protagonists. The inhibition of proliferation can be caused by various mechanisms such as the activation of cell cycle suppressors, the down-regulation of positive cell cycle regulators, or the abrogation of mitotic signalling. Therefore, we investigated by which of these mechanisms the dichloromethane extract of $P$. odorata accomplished cell cycle arrest. Extract $(4 \mathrm{mg} / \mathrm{ml})$ caused the decrease of Cdc25A levels within $24 \mathrm{~h}$ of treatment 
a

Pluchea odorata

Co $\begin{array}{llllll}0.5 & 2 & 4 & 8 & 24\end{array}$

phospho-Chk2

Chk2

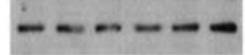

Cdc25A

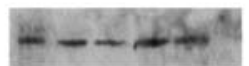

cyclin D1

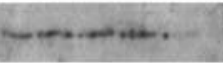

p27

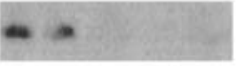

$\beta$-actin

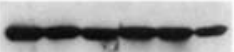

b Pluchea odorata

Lactuca sativa

Co $0.5224 \quad 824$

phospho-Erk

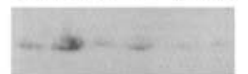

Erk

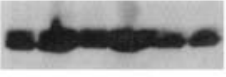

$\beta$-actin

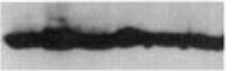

cyclin D1

$$
\text { p27 }
$$

Lactuca sativa

Co $0.5 \quad 2 \quad 4 \quad 4 \quad 8 \quad 24$
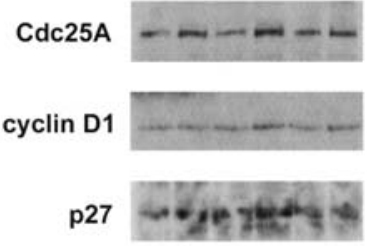

$\beta$-actin

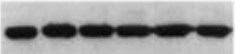

which was preceded by an activating phosphorylation of Chk2 (Fig. 5a). Chk2 was shown to target Cdc25A to proteasomal degradation. Also cyclin D1 levels dropped within $8 \mathrm{~h}$ (Fig. 5a). Whereas cyclin D1 is required to allow G1-S transit, Cdc25A is necessary for both, G1-S and G2-M transit. In this way, $P$. odorata extract interfered with cell cycle progression. On the other hand, p2 $1^{\text {waf }}$ cell cycle inhibitor did not become induced (data not shown) and constitutive p27kip expression even became suppressed (Fig. 5a) and therefore, did not correlate with cell cycle inhibition. In contrast, treatment with $4 \mathrm{mg} / \mathrm{ml}$ dichloromethane extract of $L$. sativa,

which did not affect HL-60 proliferation, did not suppress p27 kip levels. Furthermore, neither Cdc25A nor cyclin D1 levels changed when HL-60 cells were treated with $L$. sativa extract (Fig. 5a). Finally, a major transducer of mitotic signalling, Erk (MAPK) became dephosphorylated and therefore inactivated after $8 \mathrm{~h}$ of treatment (Fig. 5b). Unexpectedly, L. sativa control extract caused strong and unusually long-lasting phosphorylation of Erk, although cell proliferation did not increase in speed. Therefore, the

\section{Apoptosis induction by Pluchea odorata}

HL-60
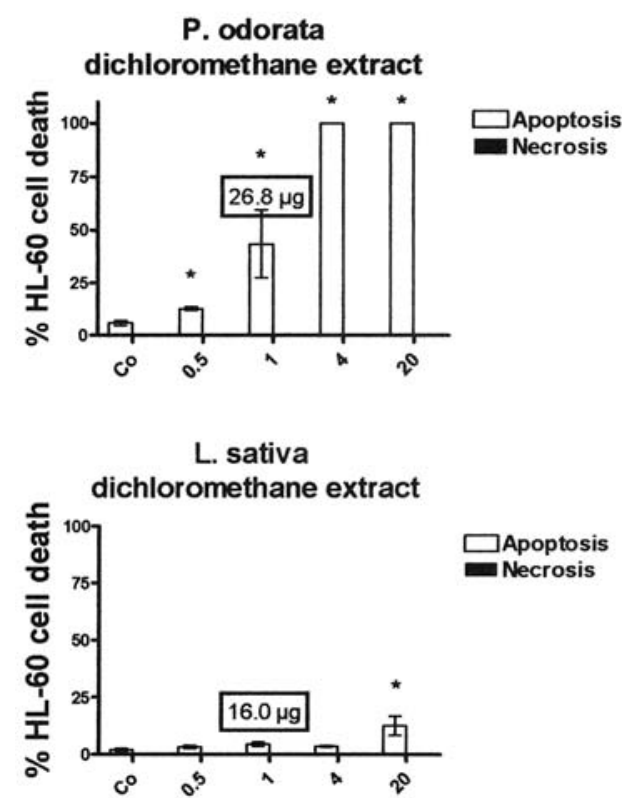

MCF-7
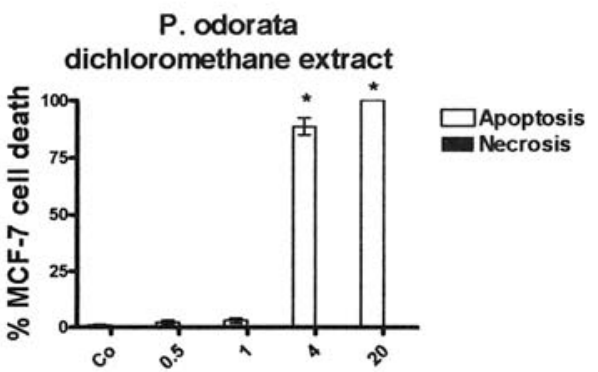

L. sativa dichloromethane extract

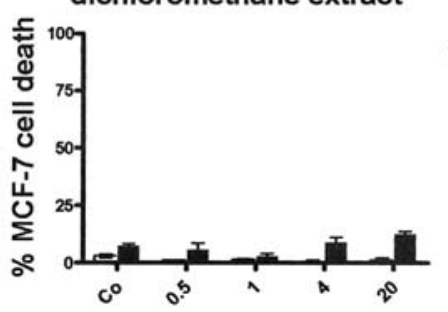

Figure 6. Induction of apoptosis and necrosis by the dichloromethane extract of $P$. odorata. HL-60 cells were incubated for $48 \mathrm{~h}$ and MCF-7 cells for $96 \mathrm{~h}$ with increasing extract concentrations. Then, cells were double stained with Hoechst 33258 and propidium iodide and examined under the microscope with UV light and a DAPI filter. Nuclei with morphological changes which indicated apoptosis or necrosis (Materials and methods) were counted and percentages of vital, apoptotic and necrotic cells were calculated. Boxed $\mu \mathrm{g}$-amounts refer to dried extract weights per ml cell culture medium and show that the extract activity is very high. Error bars indicate SEM, and asterisks significant apoptosis induction compared to control ( $\mathrm{p}<0.05)$. 
Pluchea odorata

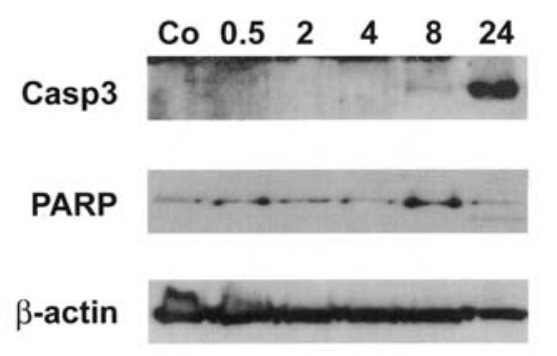

Lactuca sativa

Co $\begin{array}{lllll}0.5 & 2 & 4 & 8 & 24\end{array}$

Casp3

PARP

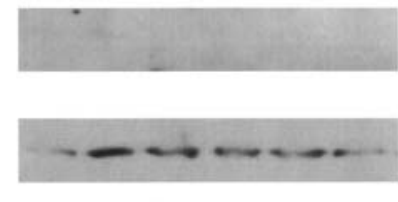

$\beta$-actin

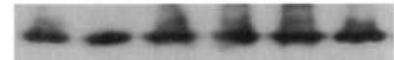

Figure 7. Western blot analysis of pro-apoptotic caspase- 3 and its target PARP. HL-60 cells (1x10 6 cells) were seeded into T-75 tissue culture flasks and allowed to grow for $24 \mathrm{~h}$ when cells were incubated with $4 \mathrm{mg} / \mathrm{ml}$ dichloromethane extract derived from $P$. odorata and L. sativa for $0.5,2,4,8$ and $24 \mathrm{~h}$. Then isolated protein samples were subjected to electrophoretic separation and subsequent Western blot analysis using antibodies against: caspase-3 which recognizes only the cleavage product indicating caspase activation, PARP which recognizes the full length form (116 kDa) and the signature-type cleaved product $(85 \mathrm{kDa})$ which is generated by active caspase-3. Equal sample loading was controlled by Poinceau S staining and $\mathrm{B}$-actin analysis.

Co $\begin{array}{lllll}0.5 & 2 & 4 & 8 & 24\end{array}$

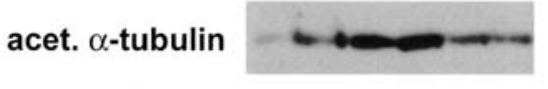

$\alpha$-tubulin

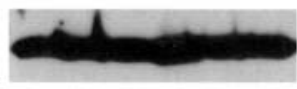

$\beta$-tubulin

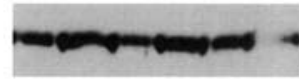

$\beta$-actin

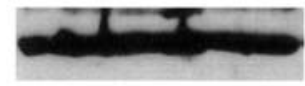

acet. $\alpha$-tubulin

Co $\begin{array}{lllll}2 & 4 & 8 & 24\end{array}$
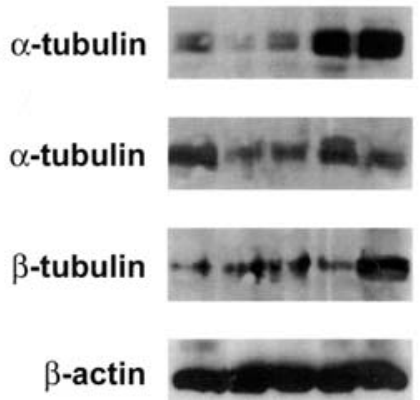

Figure 8 . Western blot analysis of tubulin acetylation. HL-60 cells ( $1 \times 10^{6}$ cells) were seeded into T-75 tissue culture flasks and allowed to grow for 24 h when cells were incubated with $4 \mathrm{mg} / \mathrm{ml}$ dichloromethane extract derived from $P$. odorata (left panel) and $1 \mu \mathrm{M}$ paclitaxel (right panel) for $2,4,8$ and $24 \mathrm{~h}$. Then, isolated protein samples were subjected to electrophoretic separation and subsequent Western blot analysis using antibodies against: acetylated- $\alpha$-tubulin, $\alpha$-tubulin and $\beta$-tubulin. Equal sample loading was controlled by Poinceau S staining and $\beta$-actin analysis.

phosphorylation level of Erk did not correlate with the proliferation of HL-60 cells.

The dichloromethane extract of Pluchea odorata induces caspase-3 and apoptosis. The dichloromethane extract of $P$. odorata was further tested regarding pro-apoptotic properties in HL-60 and MCF-7 cells because one major property of cytotoxic anticancer drugs is the potential to elicit cancer cell death. P. odorata extract dose-dependently induced apoptotic cell death in HL-60 cells and $4 \mathrm{mg} / \mathrm{ml}$ was sufficient to eliminate $100 \%$ of HL-60 cells after $48 \mathrm{~h}$ and $~ 90 \%$ of MCF-7 cells after 96 h (Fig. 6).

Caspase- 3 is one of the key executioneers of apoptosis responsible for the signature-type cleavage of specific target proteins such as the nuclear enzyme poly (ADP-ribose) polymerase (PARP) (14). Therefore, it was investigated whether apoptotic cell death (as determined by HO/PI cell death assay) correlated with the activation of caspase- 3 and the cleavage of its target PARP. Incubation of HL-60 cells with $4 \mathrm{mg} / \mathrm{ml}$ dichloromethane extract of $P$. odorata caused the specific cleavage of caspase- 3 to $19 \mathrm{kDa}$ and $12 \mathrm{kDa}$ fragments which is indicative for its activation. The $19 \mathrm{kDa}$ fragment is recognized by this caspase- 3 antibody, which detects only the activated form, but not the inactive $30 \mathrm{kDa}$ zymogen. Once activated, caspase-3 cleaves the $116 \mathrm{kDa}$ death substrate PARP into a $85 \mathrm{kDa}$ fragment. Western blot analysis showed that caspase- 3 activation preceded PARP signature type cleavage thereby evidencing that caspase-3 was in fact functional (Fig. 7). Thus, apoptotic cell death triggered by dichloromethane extract of P. odorata was executed by caspase- 3 . In contrast, the dichloromethane extract of L. sativa did not induce cell death in HL-60 or MCF-7 cells.

The deregulation of tubulin dynamics is incompatible with functional cell division (11) and the stabilization of microtubules by taxol causes mitotic arrest (mitotic catastrophe) and in consequence apoptosis. Polymerised/stabilized microtubule $(9,15)$ are reflected by the increased acetylation of $\alpha$-tubulin at lysine 40 (10), and prolonged hyper-acetylation of $\alpha$-tubulin finally marks the onset of mitotic arrest and cell death. Since disturbance of fine-tuned tubulin dynamics is incompatible with cell survival, we analysed whether the dichloromethane extract of $P$. odorata, increased the acetylation of $\alpha$-tubulin. As shown in Fig. 8, incubation of HL-60 cells with $P$. odorata dichloromethane extract induced the acetylation of $\alpha$-tubulin within 30 min which was maintained for $24 \mathrm{~h}$. Therefore, this extract type stabilised/polymerised microtubules, similar to taxol, causing mitotic catastrophe and this was most likely the prime mechanism triggering apoptosis. 


\section{Discussion}

By using extracts from plants used traditionally in Guatemala/ Belize to treat inflammatory diseases we found that the dichloromethane extract of $P$. odorata exhibited strong antiproliferative and pro-apoptotic potential most likely due to down-regulation of cyclin D1 and acetylation of $\alpha$-tubulin, respectively.

Because leukaemias are characterized by an abnormal proliferation of blood cells, mostly leukocytes, but these diseases often escape successful treatment, a novel preclinical concept was tested in the human promyeloic leukaemia cell line HL-60. We chose a highly interdisciplinary approach that involved the long lasting empirical knowledge of the Maya. This old civilization has a highly developed plantmedicinal tradition, i.e. they worship(ped) the medicinal goddess, Ix Chel. Maya medicine was unaware of leukaemia or cancer possibly because they did not live long enough and therefore, no remedies against these diseases were discovered. Our concept of plant selection is their traditional use against severe inflammations, because there is a variety of similar signalling pathways which are commonly upregulated both in inflammatory conditions and in cancer. Here we compared the in vitro anti-cancer effects of extracts of two anti-inflammatory plants, $P$. decumanum and $P$. odorata. Maya healers utilize decoctions of $P$. odorata to treat coughs, cold, neuritis, artritis and $P$. decumanum to treat stomach ulcers, gastritis and even early stage tumours (16), although $P$. decumanum cannot be recommend due to severe kidney damaging side effects. It is supposed that $P$. decumanum decreases the production of $\mathrm{TNF} \alpha$ and therefore inflammations. It is meanwhile widely accepted that self-healing processes are triggered by 'shamanic rituals' which in no little part contribute to the medicinal success (such rituals, yet in another form, also exist in Western medicine and they also add to the healing process). Therefore, to discriminate self-healing phenomena from drug-mediated effects we undertook in vitro testing to investigate whether both plants indeed exhibit anti-inflammatory properties. This was in fact the case, because the petroleum ether extract of $P$. decumanum rhizome and the dichloromethane extract of $P$. odorata aerial parts suppressed $\mathrm{TNF} \alpha$-stimulated CD62E-expression in HUVECs. However, the anti-proliferative effects which are a hallmark for anti-tumor activity were only moderate in HL-60 cells upon $P$. decumanum extract application. It can be speculated that the empirical anti-tumor effects observed by traditional healers were not due to cell cycle-inhibitory or pro-apoptotic properties (although we did not analyse the pro-apoptotic potential of $P$. decumanum, since both mechanisms mostly appear together), but due to antiangiogenic or anti-invasive properties, which have not been monitored by the methods applied here. In contrast, the anti-cancer effects of $P$. odorata, most and for all the proapoptotic properties, were strong.

To enable an initial and preliminary separation of plant components, the dried plant materials were serially/ sequentially extracted with solvents of increasing polarity, which facilitated that different chemical substances from the plants were dissolved in the various extract types. Therefore, the five solvents exhibited distinct activities. In detail, the plant extracts were tested regarding their antileukaemic potentials such as the inhibition of proliferation and the induction of leukaemia cell death because these are indicators for anti-neoplastic activities. The anti-proliferative effects of $P$. decumanum rhizome and foliage extracts were only weak to moderate (respectively). The dichloromethane extract of $P$. odorata exhibited much higher activity. In the traditional application the plants are air-dried which is a time-consuming process in the humid climate of the tropics and this may cause the degradation of active metabolites. Therefore, we compared the effectivity of the traditional vs. a modern preparation methods (freeze-drying of freshly harvested plants). Unexpectedly, the way of plant drying did not affect the activity of the $P$. odorata dichloromethane extract, because air-dried and freeze-dried plant material arrested the cell cycle similarly and at low doses. From other investigations we know that freeze-drying of plants is mandatory for the preservation of their anti-cancer activity (unpublished data).

$P$. odorata dose-dependently arrested the cell cycle in G2-M phase. The interference with three independent mitotic mechanisms may have stalled the cells in this phase: i) the dephosphorylation of p44 and p42 mitogen activated protein (MAP) kinases (synonyms: Erk1 and Erk2), which function in a protein kinase cascade that plays a critical role in the regulation of cell growth and differentiation (17-20), within $2 \mathrm{~h}$ and therefore interruption of mitotic signalling. MAP kinases are activated by a wide variety of extracellular signals and transduce these mitotic signals through phosphorylation of threonine and tyrosin residues $(21,22)$; ii) the $P$. odorata dichloromethan extract suppressed Cyclin D1 within $8 \mathrm{~h}$, which is required for the activation of $\mathrm{Cdk} 4$ and Cdk6 $(23,24)$, thereby affecting cell cycle progression. The D family of cyclins has been associated with a wide variety of proliferative diseases and cyclin D1 is classified as a proto-oncogene. Temporally the $\mathrm{D}$ cyclins appear in early G1, before the B cyclins, in the course of the cell cycle (25-27); iii) induction of checkpoint kinase 2 and consequently degradation of Cdc25A within $24 \mathrm{~h}$. Also Cdc25A is a protooncogene and coordinates the transit from G1 to $\mathrm{S}$ and also contributes to G2-M transit.

The cell cycle inhibitors p21 (which did not become up-regulated; data not shown) and p27 (which became even down-regulated) did not seem to play a role in this process.

$P$. odorata dichloromethane extract dose-dependently triggered apoptosis which was preceded by an activation of caspase- 3 and degradation of its target PARP1. The proapoptotic potential was extraordinarily high, as $25 \mu \mathrm{g} / \mathrm{ml}$ dried extract remnant (corresponding to $\sim 1 \mathrm{mg} / \mathrm{ml}$ dried plant weight) iduced $\sim 50 \%$ cell death. The activity which inhibited $50 \%$ proliferation was calculated as $0.7 \mathrm{mg} / \mathrm{ml}$ dried plant weight and it is very likely, that apoptosis had already a major contribution to this 'anti-proliferative' activity. Both mechanisms were overlapping at the time-points measured (and cannot be dissected by differently scheduled timing) and this allows the conclusion that the dichloromethane extract of P. odorata harbours an extraordinaryly potent pro-apoptotic activity, which can be exploited for the development of an anti-cancer therapeutical approach. Pluchea species were shown to contain polyphenols, terpenoids and flavonoids 
(28-31). When tested in HL-60 and other cancer cells, flavonoids and other (poly)phenolic compounds were shown to elicit apoptosis and inhibit the cell cycle. Frequently however, the proapoptotic concentrations were severalfold higher than those concentrations which inhibited proliferation (32-38). This underlines the effectiveness of the $P$. odorata extract, which may be based on the synergism of several pro-apoptotic principles.

Tubulins play a prevalent role in the differentiation of microtubule structure and function. Fine tuned orchestration of tubulin polymerization/depolymerization events are required to enable mitotic spindle arrangements and cytokinesis. Therefore, the severe affection of tubulin dynamics upon stabilization is incompatible with functional cell division (11) and causes mitotic catastrophe. Taxol exerts its anticancer effect by stabilizing/polymerizing microtubules, which in turn triggers apoptosis due to mitotic arrest $(8,9)$. On the contrary, destabilization of tubulin such as by vincristine or colchicine, is cytotoxic (9). Thus, tubulin-targeting drugs are validated anti-cancer therapeutics (39). The polymerization of microtubules such as by taxol is associated with increased acetylation of $\alpha$-tubulin, which is an established marker for microtubule stability (10), because only polymerized but not non-polymerized microtubules become acetylated $(15,40)$. Histone deacetylase 6 (HDAC6) is to date the only known enzyme specifically de-acetylating $\alpha$-tubulin (41) and hence, it controls the dynamics and stability of microtubules by promoting their disassembly (40) and inhibition of HDAC6 results in $\alpha$-tubulin acetylation on lysine 40 (11). Also the inhibition of farnesyl transferase increases $\alpha$-tubulin acetylation (9) probably due to affection of the activity of the farnesyl-carrying mitotic microtubule-associated proteins CENP-E (42).

Incubation with $P$. odorata dichloromethan extract rapidly (after $30 \mathrm{~min}$ ) increased the acetylation of $\alpha$-tubulin, that still persisted after $24 \mathrm{~h}$ of incubation. Therefore, this extract contained $\alpha$-tubulin targeting activity, reminiscent of taxol, and arrested cells in G2-M causing mitotic catastrophe and cell death. The mechanism by which $P$. odorata extract interfered with microtubule dynamics will be addressed in future investigations.

To rule out the possibility, that the dichloromethane extracts generally contain non-specific toxic components we compared a dichloromethane extract prepared from L. sativa var. capitata, the green 'iceberg' salad. Only the highest concentration tested $(20 \mathrm{mg} / \mathrm{ml})$ inhibited HL-60 cell proliferation but did not induce apoptosis and the dichloromethane rhizome extract of $P$. decumanum was even less active. At the $4 \mathrm{mg} / \mathrm{ml}$ concentration, at which also the $P$. odorata extract was investigated by FACS and by Western blot analyses, L. sativa dichloromethane extract did not inhibit Cdc25A or cyclin D1 expression nor did caspase- 3 become activated. Instead, it induced the phosphorylation of Erk although we did not observe an acceleration of proliferation.

New agents with prospective anti-cancer activity are usually tested in a panel of 60 distinct cancer cell lines representing 9 distinct tumor entities (43). However, the vast majority of all agents, which exhibit activity in the 60 cell line screen, are also active in MCF-7 breast cancer cells
(1). Therefore, the dichloromethane extract of $P$. odorata was also tested in MCF-7 breast cancer cells and found to inhibit cell proliferation by $\sim 90 \%$ at a concentration of $4 \mathrm{mg} / \mathrm{ml}$.

Upon testing whether $P$. odorata apolar dichloromethanesoluble constituents only target cancer cells we found that in the human immortalized anomalous breast epithelial cell line MCF-10A the antiproliferative effects were similar to those observed in MCF-7 cancer cells. This is most likely due to the fact that both cell lines duplicate similarly and also the vast majority of currently applied anti-cancer drugs combat cancer cells because they replicate faster than normal cells. Among polyphenols, flavonoids, and sesquiterpenes there are a plethora of bio-active compounds and studies more than 20 years ago analysed $P$. odorata regarding its constituents. It was shown that it contains flavonoids, triterpenes $(28,29)$, phytosterols (44), and Plucheinol, an eudesmane type sesquiterpene unique to $P$. odorata $(30,31)$. A comparison between two $P$. odorata populations from Mexico and El Salvador showed that the Mexican population contained a greater number of triterpenes and flavonoids, whereas the plants from El Salvador contained a greater number of sesquiterpenes $(29,45)$. Whether the different $P$. odorata populations also exhibit different anti-cancer activity needs to be established and could elucidate which type(s) of the plant constituents may be responsible for the here described effects.

\section{Acknowledgements}

We wish to thank Toni Jäger for preparing the figures. The work was supported by the Fonds for Innovative and Interdisciplinary Cancer Research to M.F-S. and G.K.; the Unruhe Privatstiftung and the Hochschuljubiläumsstiftung der Stadt Wien to G.K.

\section{References}

1. Cragg GM and Newman DJ: Antineoplastic agents from natural sources: achievements and future directions. Expert Opin Investig Drugs 9: 2783-2797, 2000.

2. Cragg GM, Newman DJ and Yang SS: Natural product extracts of plant and marine origin having antileukemia potential. The NCI experience (Review). J Nat Prod 69: 488-498, 2006.

3. Bolsover SR, Hyams JS, Shephard EA, White HA and Wiedemann CG: Cell biology: a short course. John Wiley\& Sons, Inc., Hoboken, New Jersey, 2004.

4. Ribeiro LR, Mantovani MS, Ribeiro DA and Salvadori DM: Brazilian natural dietary components (annatto, propolis and mushrooms) protecting against mutation and cancer (Review). Hum Exp Toxicol 25: 267-272, 2006

5. Rakoff-Nahoum S: Why cancer and inflammation? (Review). Yale J Biol Med 79: 123-130, 2006.

6. Federico A, Morgillo F, Tuccillo C, Ciardiello F and Loguercio C: Chronic inflammation and oxidative stress in human carcinogenesis. Int J Cancer 121: 2381-2386, 2007.

7. Hold GL and El-Omar ME: Genetic aspects of inflammation and cancer (Review). Biochem J 410: 225-235, 2008.

8. Geney R, Sun L, Pera P, Bernacki RJ, Xia S, Horwitz SB Simmerling CL and Ojima I: Use of the tubulin bound paclitaxel conformation for structure-based rational drug design. Chem Biol 12: 339-348, 2005.

9. Marcus AI, Zhou J, O'Brate A, Hamel E, Wong J, Nivens M, El-Naggar A, Yao TP, Khuri FR and Giannakakou P: The synergistic combination of the farnesyl transferase inhibitor lonafarnib and paclitaxel enhances tubulin acetylation and requires a functional tubulin deacetylase. Cancer Res 65: 3883-3893, 2005. 
10. Piperno G, LeDizet $M$ and Chang XJ: Microtubules containing acetylated alpha-tubulin in mammalian cells in culture. $\mathrm{J}$ Cell Biol 104: 289-302, 1987

11. Piperno G and Fuller M: Monoclonal antibodies specific for an acetylated form of alpha-tubulin recognize the antigen in cilia and flagella from a variety of organisms. J Cell Biol 101: 2085-2094, 1985.

12. Grusch M, Polgar D, Gfatter S, Leuhuber K, Huettenbrenner S, Leisser C, Fuhrmann G, Kassie F, Steinkellner H, Smid K, Peters GJ, Jayaram HN, Klepal W, Szekeres T, Knasmuller S and Krupitza G: Maintenance of ATP favours apoptosis over necrosis triggered by benzamide riboside. Cell Death Differ 9: 169-178, 2002

13. Huettenbrenner S, Maier S, Leisser C, Polgar D, Strasser S Grusch $\mathrm{M}$ and Krupitza G: The evolution of cell death programs as prerequisites of multicellularity (Review). Mutat Res 543: 235-249, 2003

14. Fernandes-Alnemri T, Litwack G and Alnemri ES: CPP32, a novel human apoptotic protein with homology to Caenorhabditis elegans cell death protein Ced-3 and mammalian interleukin-1 beta-converting enzyme. J Biol Chem 269 : 30761-30764, 1994

15. Wilson PJ and Forer A: Effects of nanomolar taxol on crane-fly spermatocyte spindles indicate that acetylation of kinetochore microtubules can be used as a marker of poleward tubulin flux. Cell Motil Cytoskeleton 37: 20-32, 1997.

16. Arvigo R and Balick M: Rainforest Remedies. Lotus Press, Twin Lakes, WI, 1998.

17. Marshall CJ: Specificity of receptor tyrosine kinase signaling: transient versus sustained extracellular signal-regulated kinase activation. Cell 80: 179-185, 1995.

18. Hunter T: Protein kinases and phosphatases: the yin and yang of protein phosphorylation and signaling. Cell 80: 225-236, 1995.

19. Hill CS and Treisman R: Transcriptional regulation by extracellular signals: mechanisms and specificity. Cell 80: 199-211, 1995.

20. Cowley S, Paterson H, Kemp P and Marshall CJ: Activation of MAP kinase kinase is necessary and sufficient for PC12 differentiation and for transformation of NIH 3T3 cells. Cell 77: 841-852, 1994.

21. Sturgill TW, Erikson LBRE and Maller JL: Insulin-stimulated MAP-2 kinase phosphorylates and activates ribosomal protein S6 kinase II. Nature 334: 715-718, 1988.

22. Payne DM, Rossomando AJ, Martino P. Erickson AK, Her JH, Shabanowitz J, Hunt DF, Weber MJ and Sturgill TW: Identification of the regulatory phosphorylation sites in $\mathrm{pp} 42 /$ mitogenactivated protein kinase (MAP kinase). EMBO J 10: 885-892, 1991.

23. Alao JP: The regulation of cyclin D1 degradation: roles in cancer development and the potential for therapeutic invention. Mol Cancer 6: 24, 2007.

24. Lingfei K, Pingzhang Y, Zhengguo L, Jianhua G and Yaowu Z: A study on p16, pRb, cdk4 and cyclinD1 expression in non-small cell lung cancers. Cancer Lett 130: 93-101, 1998.

25. Xiong $\mathrm{Y}$, Zhang $\mathrm{H}$ and Beach $\mathrm{D}$ : $\mathrm{D}$ type cyclins associate with multiple protein kinases and the DNA replication and repair factor PCNA. Cell 71: 504-514, 1992.

26. Xiong Y, Menninger J, Beach D and Ward DC: Molecular cloning and chromosomal mapping of CCND genes encoding human D-type cyclins. Genomics 13: 575-584, 1992.

27. Inaba T, Matsushime J, Beach D and Ward DC: Genomic organization, chromosomal localization, and independent expression of human cyclin D genes. Genomics 13: 565-574, 1992.

28. Alonso-Lopez M, Arriaga-Giner FJ, Borges-del-Castillo J and Vasquez-Bueno P: N-alkanes and triterpenoids from some Salvadorian compositae. Fitoterapia 56: 123-125, 1985.

29. Wollenweber E, Mann K, Arriaga FJ and Yatskievych G: Flavonoids and terpenoids from the leaf resin of Pluchea odorata. J Biosciences 40C: 321-324, 1985.

30. Arriaga FJ and Borges-del-Castillo J: A new eudesmane derivative from Pluchea odorata. Planta Med 51: 290, 1985 .
31. Arriaga FJ and Borges-del-Castillo J: Carbon-13 NMR spectra of Plucheinol and its ester derivatives. Magn Res Chem 23: 478-488, 1985.

32. Bader Y, Madlener S, Strasser S, Maier S, Saiko P, Stark N, Popescu R, Huber D, Gollinger M, Erker T, Handler N, Szakmary A, Jäger W, Kopp B, Tentes I, Fritzer-Szekeres M, Krupitza G and Szekeres T: Stilbene analogues affect cell cycle progression and apoptosis independently of each other in an MCF-7 array of clones with distinct genetic and chemoresistant backgrounds. Oncol Rep 19: 801-810, 2008.

33. Madlener S, Illmer C, Horvath Z, Saiko P, Losert A, Herbacek I, Grusch M, Elford HL, Krupitza G, Bernhaus A, FritzerSzekeres M and Szekeres T: Gallic acid inhibits ribonucleotide reductase and cyclooxygenases in human HL-60 promyelocytic leukemia cells. Cancer Lett 245: 156-162, 2007.

34. Saiko P, Ozsvar-Kozma M, Bernhaus A, Jaschke M, Graser G, Lackner A, Grusch M, Horvath Z, Madlener S, Krupitza G, Handler N, Erker T, Jaeger W, Fritzer-Szekeres M and Szekeres T: N-hydroxy-N'-(3,4,5-trimethoxyphenyl)-3,4,5-trimethoxybenzamidine, a novel resveratrol analog, inhibits ribonucleotide reductase in HL-60 human promyelocytic leukemia cells: synergistic antitumor activity with arabinofuranosylcytosine. Int J Oncol 31: 1261-1266, 2007.

35. Horvath Z, Murias M, Saiko P, Erker T, Handler N, Madlener S, Jaeger W, Grusch M, Fritzer-Szekeres M, Krupitza G and Szekeres T: Cytotoxic and biochemical effects of 3,3',4,4',5,5'hexahydroxystilbene, a novel resveratrol analog in HL-60 human promyelocytic leukemia cells. Exp Hematol 34: 1377-1384, 2006.

36. Grusch M, Fritzer-Szekeres M, Fuhrmann G, Rosenberger G Luxbacher C, Elford HL, Smid K, Peters GJ, Szekeres T and Krupitza G: Activation of caspases and induction of apoptosis by novel ribonucleotide reductase inhibitors amidox and didox. Exp Hematol 29: 623-632, 2001.

37. Rosenberger G, Fuhrmann G, Grusch M, Fassl S, Elford HL, Smid K, Peters GJ, Szekeres T and Krupitza G: The ribonucleotide reductase inhibitor trimidox induces c-myc and apoptosis of human ovarian carcinoma cells. Life Sci 67: 31313142, 2000

38. Fritzer-Szekeres M, Grusch M, Luxbacher C, Horvath S, Krupitza G, Elford HL and Szekeres T: Trimidox, an inhibitor of ribonucleotide reductase, induces apoptosis and activates caspases in HL-60 promyelocytic leukemia cells. Exp Hematol 28: 924-930, 2000

39. Jordan MA and Wilson L: Microtubules as a target for anticancer drugs (Review). Nat Rev Cancer 4: 253-265, 2004.

40. Matsuyama A, Shimazu T, Sumida Y, Saito A, Yoshimatsu Y, Seigneurin-Berny D, Osada H, Komatsu Y, Nishino N, Khochbin S, Horinouchi S and Yoshida M: In vivo destabilization of dynamic microtubules by HDAC6-mediated deacetylation. EMBO J 21: 6820-6831, 2002.

41. Hubbert C, Guardiola A, Shao R, Kawaguchi Y, Ito A, Nixon A, Yoshida M, Wang XF and Yao TP: HDAC6 is a microtubuleassociated deacetylase. Nature 23;417: 455-458, 2002.

42. Crespo NC, Delarue F, Ohkanda J, Carrico D, Hamilton AD and Sebti SM: The farnesyl-transferase inhibitor, FTI-2153, inhibits bipolar spindle formation during mitosis independently of transformation and Ras and p53 mutation status. Cell Death Differ 9: 702-709, 2002

43. Weinstein JN, Myers TG, O'Connor PM, Friend SH, Fornace AJ Jr, Kohn KW, Fojo T, Bates SE, Rubinstein LV, Anderson NL, Buolamwini JK, van Osdol WW, Monks AP, Scudiero DA, Sausville EA, Zaharevitz DW, Bunow B, Viswanadhan VN, Johnson GS, Wittes RE and Paull KD: An information-intensive approach to the molecular pharmacology of cancer. Science 275: 343-349, 1997.

44. Dominguez XA and Zamudio A: B-amyrin acetate and campestereol from Pluchea odorata. Phytochemistry 11: 1179, 1972.

45. Arriaga-Giner FJ, Borges-del-Castillo J, Manresa-Ferrero MT, Vasquez-Bueno P, Rodriguez-Luis F and Valdes-Iraheta S: Eudesmane derivatives from Pluchea odorata. Phytochemistry 22: 1767-1769, 1983 . 